\title{
THE USAGE OF JARIMATIKA METHODS TO IMPROVE COUNTING SKILLS ABILITY FOR LOW-GRADE STUDENTS
}

\author{
Ihsanudin $^{1}$, dan Trian Pamungkas Alamsyah ${ }^{2}$ \\ ${ }^{1,2}$ FKIP, Universitas Sultan Ageng Tirtayasa \\ Email: ihsanudin1797@untirta.ac.id; trian@untirta.ac.id
}

\begin{tabular}{l}
\hline Info Artikel \\
\hline Sejarah Artikel: \\
Diserahkan 6 Maret 2019 \\
Direvisi 12 November 2019 \\
Disetujui 23 November 2019 \\
\hline
\end{tabular}

Keywords:

counting ability, jarimatika

\author{
Abstract \\ The purpose of this research is to find the usage of Jarimatika method in improving \\ counting skills ability for low grade students on multiplication 6 to 10. \\ The method used in this study is a quasi-experimental method. The sample of this study is \\ grade III elementary school. Sample selection by purposive sampling. The study was \\ conducted at SD Banjar Agung 4 Serang Regency with a population of all class III at the \\ elementary school. Data was collected using several techniques of documentation, \\ observation, tests and interviews. This study uses a prerequisite test that is normality test \\ and homogeneity test using SPSS 19 program. \\ The results of this study, there is an improvement in students' counting skills on \\ multiplication 6 to 10 which can be seen by increasing the average score of students in the \\ post test and based on the calculation of the t test with a significant value of 0.343 \\ (exceeded the value of 0.05 ) and students are more enthusiastic and not quickly forget the \\ multiplication calculation.
}

\begin{abstract}
Abstrak
Tujuan penelitian ini untuk mengetahui metode jarimatika dapat meningkatkan kemampuan berhitung bagi peserta didik kelas rendah pada perkalian 6 sampai dengan 10 .

Metode yang digunakan dalam penelitian ini yaitu metode kuasi eksperimen. Sampel penelitian ini adalah kelas III Sekolah dasar. Pemilihan sampel secara purposive sampling. Penelitian dilaksanakan di SD Banjar Agung 4 Kabupaten Serang dengan populasi seluruh kelas III pada SD tersebut. Data dikumpulkan dengan menggunakan beberapa teknik dokumentasi, observasi, tes dan wawancara. Penelitian ini menggunakan uji prasyarat yaitu uji normalitas dan uji homogenitas menggunakan progam SPSS 19.

Hasil dari penelitian ini terdapat peningkatan kemampuan berhitung peserta didik pada perkalian 6 sampai dengan 10 yang ditandai dengan peningkatan nilai rata-rata peserta didik pada post tes dan berdasarkan perhitungan uji t dengan nilai signifikan 0,343 (melebihi nilai 0,05 ) dan peserta didik lebih bersemangat dan tidak cepat lupa pada perhitungan perkalian.
\end{abstract}

C 2019 Universitas Muria Kudus 
Ihsanudin dan Trian Pamungkas Alamsyah

THE USAGE OF JARIMATIKA METHODS TO IMPROVE COUNTING SKILLS ABILITY FOR ... REFLEKSI EDUKATIKA : Jurnal Ilmiah Kependidikan 10 (1) Desember 2019. Hlm. 10-17

\section{INTRODUCTION}

The rapid development of science and technology has accompanied changes in various aspects of life including education. Education becomes one of the most important parts of the development process and the improvement of human resources. Education can influence the development of one's life by maximizing selfpotential. Education is a conscious and systematic effort that made by people who are entrusted with the responsibility to influence students to have the characteristics and behavior that have accordance with the ideals education (Munib, 2010). The implementation of quality education had to be done to realize the ideals of education in every education unit, including in basic education.

Basic education are aims to make students becomereligious, devoted, creative and innovative, and have scientific insight and ready to continue their education in the next stage. The efforts that can be made to achieve the goals of basic education can be achieved by preparing learning media. Learning media are intended to facilitate students in achieving the educational goals. In this case, the main lessonare included in the learning media. The main lesson is a lesson that must be taught by educators, so the students can have skills. One of the main lessons at the elementary school level are Mathematics.

Mathematics is one of the main lesson that must be mastered by children and very useful for students in their daily life. Cockroft, as quoted by Abdurrahman (2010), states that mathematics needs to be taught to students because it always used in all aspects of life. Mathematics is a strong, concise and clear communication tools, can be used to present information in various ways, increase the desire of thinking logically, accuracy, and spatial awareness and provide satisfaction with efforts to solve the challenging problems. Mathematics has an important role in various scientific disciplines, it also serves to develop the ability to communicate with numbers and symbols,and thoughts that may help to clarify and resolve the problems in daily life.

One of the characteristics of mathematics are having the abstract objects because the characteristic of mathematical objects are abstract, it generally makes the material of mathematics are difficult to understand.
Considering that objects in mathematics are abstract, then the right media are needed to be the mediator of mathematics learning process, so that the mathematics lesson can be understood easily by students. The use of an appropriate media can create a better learning process, in order to create the learning outcomes.

In mathematics learning on elementary school, especially on low-grade, mathematical learning are emphasized on four basic counting skills, there are the ability to calculating addition, subtraction, multiplication, and division. These four basic of counting skills are really important to be mastered as a provision of further material in the higher classand students have the competence to obtain and to use information.

The purpose of mathematics learning by Curriculum of 2013 (Kemendikbud, 2013) emphasizing the modern pedagogical dimension of learning, which uses a scientific approach. In mathematics learning, the activities that are conducted so the learning becomes meaningful areobserving, asking, trying, reasoning, presenting, and creating. To achieve these goals, mathematics learning in elementary schoorequires teachers to be able to choose and use techniques that are able to involve students in learning. Learning activities should optimize the involvement of all the senses of students. When learning mathematics, should not use memorization only, but further than that, mastery of mathematics such as formulating problems, calculating, and making conclusions need to be supported by the teacher's ability to make students learn.

Moreover, mathematics has an important role for human survival. Agreed with Turmudi (2009) mathematics is closely related to daily life, so the children are able to apply mathematics in a useful contextsto them. Other than that, learning mathematics can familiarize someone with critical and logical thinking, and can increase their potency of creativity.

Maknumas quoted by Taufik (2014) argues that elementary school age children aged 7 to 11 are in concrete operational stages according to Jean Piaget's theory. This means that at this stagthey have been able to understand the logical operations and support concrete objects. Low-grade students of elementary school level are in the process of growth onall aspectswhether cognitive, affective and 
Ihsanudin dan Trian Pamungkas Alamsyah

THE USAGE OF JARIMATIKA METHODS TO IMPROVE COUNTING SKILLS ABILITY FOR ... REFLEKSI EDUKATIKA : Jurnal Ilmiah Kependidikan 10 (1) Desember 2019. Hlm. 10-17

psychomotor to develop the most basic readwrite-count abilities that must be mastered by each student, especially low-grade students.

Wanabuliandari (2016) estates the concept of learning can be implemented if the information are interesting and motivates students to keep on learning. Therefore, before conducting learning activities in the classroom, teachers must be able to preparing and designing learning that are interesting and able to grow student activities. Learning in elementary school will be more effective, creative, and fun if uses various media and methods in various ways. Varied learning are aims to create student learning interests and motivations for all subjects in school. Mathematics lessons in basic education, especially low-gradesin fact are still classified to basic, but the implementation should be properly explain the basic concepts appropriately. This anticipation are done to avoid students in having mathematics learning difficulties on the further stage. There are still many uses for multiplication operations as a recurrent addition. Students have difficulty in solving problems that related to counting multiplication operations. The low ability of students may be influenced by the less effective of learning techniques, and the lack of optimal development of the mathematics application in daily life to the material that being studied,so the students feel tired and bored. This condition is caused by the learning that done by the teachers are tends to be far from self-students in the learning process. Therefore, it requires appropriate techniques so it enable each students to be more interested to learn actively.

This finding reinforces previous research by Anwar (2012). Among the obstacles faced, such as; 1) Some students' motivation in learning mathematics are still low, 2) Students' ability in capturing the material presented are different, so it may hamper the learning process, 3) the availability of textbooks as a guide for exercise of students are still lacking, (4) the available time is still insufficient compared to the material that must be taught.

In multiplication skills, there are still many teachers who use the repeated addition method. In repeated addition requires considerable time. With this method, students are often to make mistakes that come from students' difficulties in repeated addition or careless.
Another method that are often used by teachers is memorizing multiplication. Consequently, students feel lazy and less interested.

Not infrequently, teachers are often forget the principles of teaching math in elementary school. There are several things that must be considered when teaching mathematics, as follows: 1) Instill the process of learning in counting like practice (drilling), memorization and tests are adequate, but it will be more effective if the teachers encourages students' creativity by helping them to understand the basic ideas and principles of counting through those activities. Teaching math based on the understanding will lead to the better memory andtransferability, 2) In presenting the new topics, it should begin from the simplest stages to complex stages, from the concrete to the abstract, from the closer environment of the children towards to the broader environment, 3) Children's social experiences and the application of concrete objects need to be done by teachers to help children to understand the meaning of counting, 4) Every step in calculation teaching should be attempted through an interesting presentation to avoid the occurrences of pressure or tenseness of the child, 5) Every child learns with their own readiness and comprehension. The teacher's duty besides the readiness motivation are also provides a varied and effective experience, 6) Exercises are very important to strengthen the understanding and skills 7) The relevance of counting with everyday life needs to be emphasized. Therefore the calculating lessons that obtained by children will be more meaningful to them and furthermore they can apply it in daily life. Therefore, teachers need to make planned preparations so the children can get a diverse and functional learning experience.

To support the principles of calculation teaching in elementary schools, many methods are used by teachers to make children be more understand the material that being taught, but the methods provided are often less ineffective because they are less appropriate with the material and characteristics of the students. In terms of the characteristics of students in lowgrade, they can already calculate the addition and subtraction quite well. But in calculating multiplication and division they often feel difficulty. 
Ihsanudin dan Trian Pamungkas Alamsyah

THE USAGE OF JARIMATIKA METHODS TO IMPROVE COUNTING SKILLS ABILITY FOR ... REFLEKSI EDUKATIKA : Jurnal Ilmiah Kependidikan 10 (1) Desember 2019. Hlm. 10-17

One of the method that can help calculate multiplication is the Jarimatika method. Jarimatika method is a way of calculating mathematics using finger aids. Jarimatika is one of the way to perform counting operations. If we do counting exercises repeatedly with the students, the students will surely master this skill well. Jarimatika can help students to recognize the counting process and counting procedures in an easy and fun way (Wulandari2012). This is in line with Prasetyono's opinion (2009) Jarimatika method is a way of calculating mathematics using finger aids. The Jarimatika method that referred in this study is the practice of conducting multiplication operations by students using finger aids. The students' fingers are used to help the operation of counting numbers with the results of two numbers. Jarimatika method (finger and arithmetic) introduces to students that mathematics (especially counting) are fun. Counting using fingers, the students are expected to count quickly.

This research was conducted in SD Banjar Agung 4 on $3^{\text {rd }}$ grade elementary school through interview/observation. In the process of interview/observation, researchers find that the teachers in $3^{\text {rd }}$ grade still using the memorization method. The teacher communicate multiplication lesson and emphasizes to students to memorize multiplication as an effort to strengthen the lesson. This shows the lack of teachers' creative in choosing the method of learning mathematics in the classroom. Basically, the learning in elementary schools, especially in the low-grade prioritizes more on the learning to read, write and count.

Counting learning are very emphasized in elementary school students as a basis for developing learning. If the learning using lecture method are still done to the students, then they are not have interest in the material of learning multiplication operation. This can be seen from students who have not mastered multiplication operation material. Therefore, researchers wanted to know the use of Jarimatika method which is expected to improve the counting skills of low-grade students. The use of jarimatika method become an innovation in the counting learning. The use of fingers in the learning process can easier students to understand count operations.
The research about the use of Jarimatika method that was conducted by Elita (2012) with the title Effectiveness of the Jarimatika method in increasing multiplication skills for children's learning difficulties. In her research, shows that: (1) Jarimatika method can be used by students who have mathematics learning difficulties in completing multiplication operations correctly. (2) Jarimatika are considered effective in improving the ability of students who have mathematics learning difficulties,especially in solving several problem of multiplication operations 6 to 9 as many as 20 questions. This empirical study become the basis research of the use of Jarimatika methods to improve counting skills for low-grade students.

\section{RESEARCH METHODOLOGY}

The method that been used in this research is a quasi-experimental method. According to Sugiyono (2015) The experimental research is a research method that is used to find the effect of certain treatments to others in a controlledconditions. The experimental design that used in this study was a quasi-experimental research design. The form of quasi-experiment used is the Randomized Control Group Pre-test and Post-test Design.

This research will take an experimental design that involving two groups. The first group that referred as the experimental group was given a counting learning treatment with jarimatika and the second group are called as the control group by using memorization method as the counting learning treatment. The sample of this research was the $3^{\text {rd }}$ grade elementary school, the selection of samples by "purposive sampling". Purposive sampling is a selection of samples based on the considerations and objectives of the researcher.

The research was conducted in SD Banjar Agung 4 on $3^{\text {rd }}$ grade elementary school as the population and sample. The data was collected using several data collection techniques inthe form of documentation, observation, tests and interviews.

This research uses a prerequisite test, which including 1) Normality test, this test is used to find out whether the data is normally distributed or not. The SPSS V 19.0 program was used to analyze the normality of this research. 2) Homogeneity test, this test was used to find out whether the experimental and control group have 
Ihsanudin dan Trian Pamungkas Alamsyah

THE USAGE OF JARIMATIKA METHODS TO IMPROVE COUNTING SKILLS ABILITY FOR ... REFLEKSI EDUKATIKA : Jurnal Ilmiah Kependidikan 10 (1) Desember 2019. Hlm. 10-17

the same variants or not. The SPSS 19.0 program was used to analyze the homogeneity of this research

\section{RESULT AND DISCUSSION}

The research data was taken in elementary school. SD Banjar Agung on $3^{\text {rd }} \mathrm{A}$ grade elementary school as the experimental group, $3^{\text {rd }} \mathrm{B}$ grade as the control group. The experimental group applies learning with jarimatika practice while the control group applies the memorization method. Learning begins with the teacher by instilling the concept of addition counting, because multiplication is a repeated addition. In the initial process of learning, students are introduced to the symbol of the number that is converted to the teacher's fingers, after that the students are shown the video of Jarimatika learning and demonstrated by the teachers then followed by the students. After students are considered able to counting multiplication with fingers, then they are given exercises. The multiplication learning results with Jarimatika method show an improvement based on the t-test, which is indicated by a significant value of 0.343 (more than 0,05 ).

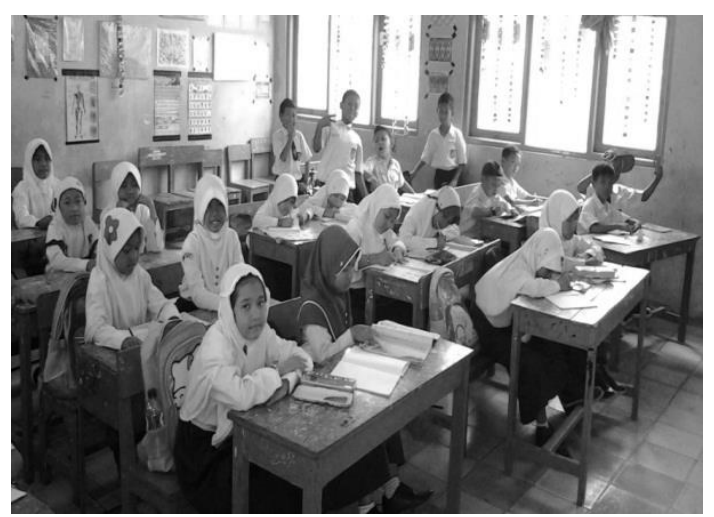

Picture 1 Jarimatika demonstration scene

The data that obtained in this study are results of pre-test and post-test of $3^{\text {rd }}$ grade students in learning mathematics by applying the practice of jarimatika in the experimental group and imaginary counting methods on the control group. After implemented the pre-test and posttest, then it does the initial data analysis.
Based on the data on pre-test and post-test scores, the average pre-test and post-test scores of the low-grade counting skills for experimental class and control class are shown in table 1 below:

Table 1

Average Score of Pre-test, Post-test and Gain Couting Ability For Low-Grade Students

\begin{tabular}{cccc}
\hline Group & Pre-test & Post-test & Gain \\
\hline Experimental & 13.43 & 22.23 & 0.25 \\
Control & 13.53 & 21.70 & 0.24 \\
\hline
\end{tabular}

In table 1 , shows the average score of the counting skills pretest for low-grade students are relatively the same, which is the score of control group is 13.43 and for the experimental group is 13.53. This shows that, before learning students have not been able to solve multiplication counting problems, but after being treated, the multiplication test results of 6 to 10 were increasedThen if the post-test average score of the two groups is compared, that is 22.23 for experimental group and 21.70 for control group, obtained that the average score of post-test was higher than the average score of pre-test.

The gain that used in this research is the normalized gain for experimental group and control group. The gain of experimental group and control group are normally distributed and homogeneous, the mean difference test that used is the one-party test (right side). This t-test aims to see whether the improvement on counting skills for low-grade students in multiplication 6 to 10 with jarimatika method is better or equal to the memorization method, as for the hypothesis that proposed are:

Hypothesis :

$H_{0}$ :The improvement on counting skills for low-grade students in multiplication 6 to 10 with jarimatika method are not good or the same as memorization method.

$H_{1}$ :The improvement of counting skills for low-grade students on multiplication 6 to 10 with jarimatika method are better than memorization method.

With testing criteria score of sig. $>0.05$ then $\mathrm{H}_{1}$ is accepted. The calculation results with SPSS 19 software are shown as in table 2 
Table2

T-test Data Gain

Independent Samples Test

\begin{tabular}{|c|c|c|c|c|c|c|c|c|c|}
\hline & \multicolumn{2}{|c|}{\begin{tabular}{|c|} 
Levene's Test for \\
Equality of \\
Variances
\end{tabular}} & \multicolumn{7}{|c|}{ T-test for Equality of Means } \\
\hline & \multirow[b]{2}{*}{$\mathbf{F}$} & \multirow[b]{2}{*}{ Sig. } & \multirow[b]{2}{*}{$\mathbf{T}$} & \multirow[b]{2}{*}{ Df } & \multirow{2}{*}{$\begin{array}{c}\text { Sig. } \\
\text { (2-tailed) }\end{array}$} & \multirow{2}{*}{$\begin{array}{c}\text { Mean } \\
\text { Difference }\end{array}$} & \multirow{2}{*}{$\begin{array}{l}\text { Std. Error } \\
\text { Difference }\end{array}$} & \multicolumn{2}{|c|}{\begin{tabular}{|c}
$95 \%$ Confidence \\
Interval of the \\
Difference \\
\end{tabular}} \\
\hline & & & & & & & & Lower & Upper \\
\hline $\begin{array}{c}\text { Gain Equal variances } \\
\text { assumed } \\
\text { Equal variances } \\
\text { not assumed }\end{array}$ & .914 & .343 & $\begin{array}{l}-.282 \\
-.282\end{array}$ & $\begin{array}{c}58 \\
55.50\end{array}$ & $\begin{array}{l}.779 \\
.779\end{array}$ & $\begin{array}{l}-.012 \\
-.012\end{array}$ & $\begin{array}{l}.044 \\
.044\end{array}$ & $\begin{array}{l}-.101 \\
-.101\end{array}$ & $\begin{array}{l}.076 \\
.076\end{array}$ \\
\hline
\end{tabular}

Based on the calculation, the Sig score is 0.343 and the conclusion is Sig.> 0.05, which means $\mathrm{H}_{1}$ is accepted, the improvement in counting skills for low-grade students on multiplication 6 to 10 with jarimatika method are better than memorization method.

Based on the data above, can be obtained that the two group have the differences in average scores, the learning that applies jarimatika method are better than learning using the memorization method.This finding reinforces the previous research by Sitio (2017) the use of jarimatika method can improve the mathematics learning results of $1^{\text {st }}$ grade students. Jarimatika method makes students become more active in mathematics learning.

In line with these findings, Ahmadi and Weijun (2014) The results of the research showed that the counting ability of children had increased significantly as seen from their final score at the pre-test and post-test. The teachers also improved their performance, how to think about good learning using Jarimatika as the media, the results showed in quantitative data with classroom action research and teacher's action plans.

The research showed a significant contribution between the jarimatika method and students' counting skills, which was shown in the higher post-test scores. The skill of multiplication counting which influenced by jarimatika method are inseparable from the growing interest in learning of students in performing counting operations. Students become more happier to perform multiplication operations. This is because they use their fingers in learning. The use of jarimatika as an alternative counting tools is highly recommended to help students in performing multiplication operations. This is supported by the previous research Wulandari S (2013) Jarimatika introduces to children that mathematics is fun. Jarimatika techniques are used by students to be skilled in counting correctly using their finger.

Another research by Asih (2009) the research showed an improvement in the mean score of mathematics learning achievement between before and after treatment. The increased scores on the test of mathematics learning achievement were obtained by all students after applying the Jarimatika method. This inform that the jarimatika method are significantly influence the improvement in understanding the concept of addition and subtraction in $1^{\text {st }}$ and $2^{\text {nd }}$ grade of elementary school students. The findings that support further are by Nurani and Ramadhani(2014) The results of the study showed that the use of Jarimatika method on Jarimatika interactive books is easy to use and fun,because jarimatika are able to bridge up between the cognitive development stage of students with abstract calculating material so they will feel like playing while learning.

\section{CONCLUSION}

Based on the results of this research regarding the application of Jarimatika method 
Ihsanudin dan Trian Pamungkas Alamsyah

THE USAGE OF JARIMATIKA METHODS TO IMPROVE COUNTING SKILLS ABILITY FOR ... REFLEKSI EDUKATIKA : Jurnal Ilmiah Kependidikan 10 (1) Desember 2019. Hlm. 10-17

for multiplication 6 to 10 in SD Banjar Agung 4 on $3^{\text {rd }}$ grade elementary school,can be concluded that there is an improvement in counting skills of students in multiplication 6 to 10and students are more enthusiastic and do not easily forget the concept of counting multiplication, students can use their limbs especially their finger as the learning tools.

Seeing the discussion of the results and research conclusions relating to the Jarimatika method that has been done, the researcher put forward several suggestions, which are:

1. We recommend that teachers to teach students about the lessons with their own limbs or finger more often than before.

2. We recommend that teachers use Jarimatika method more often so its application can runs well, especially in mathematics.

3. The teachers can find another learning methods that can attract students in learning to avoid tiredness and boredom.

4. This research are expected to be the consideration for teachers in choosing learning methods to improve students' learning outcomes.

\section{REFERENCES}

Abdurrahman, M. 2010. Pendidikan Bagi Anak Berkesulitan Belajar. Jakarta: RinekaCipta.

Ahmadi, Farid dan Wang Weijun. 2014. The Effect of "jarimatika" Multimedia in Counting Ability of Children. Information and Knowledge Management,4 (6): 40-46.

Anwar, Zul. 2012. Pelaksanaan Pembelajaran Matematika di Sekolah Dasar. Jurnal Penelitian Ilmu Pendidikan, 5 (2):24-32.

Anugraheni, Indri. 2018. Pengembangan Perangkat Pembelajaran Matematika Berbasis Pendidikan Karakter Kreatif Di Sekolah Dasar. Refleksi Edukatika: Jurnal Ilmiah Kependidikan, 8 (2): 132-138.

Asih, Ni Made. 2009. Penerapan Metode Jarimatika Untuk Meningkatkan Pemahaman Konsep Penjumlahan dan Pengurangan pada Peserta Didik Kelas 1 dan 2 SDN 6 Sesetan, Denpasar Selatan.
Jurnal Pendidikan dan Pembelajaran, 16 (1): $1-8$.

Elita, Sandra. 2012. Efektifitas Metode Jarimatika Dalam Meningkatkan Kemampuan Perkalian Bagi Anak Kesulitan Belajar. Jurnal Ilmiah Pendidikan Khusus, 1 (1): 23-34.

Kemendikbud. 2013. Kerangka Dasar dan Struktur Kurikulum 2013. Jakarta: Kemendikbud.

Munib, Achmad et al. 2010. Pengantar Ilmu Pendidikan. Semarang: Unnes Press.

Nurani, Ainin., dan Ramadhani, Nugrahardi. 2014. Perancangan Buku Interaktif Jarimatika Penjumlahan dan Pengurangan Sebagai Alternatif Pembelajaran Matematika Untuk Anak Usia 5-7 Tahun. Jurnal Sains dan SenPomits, 3 (1): 13-17.

Prasetyono, Dwi Sunar, et al. 2009. Pintar Jarimatika. Jogjakarta: Diva Press.

Separtien, Retno. 2016. Peningkatan Hasil Belajar Matematika Melalui Media Tabel Dengan Power Point Pada Siswa Sekolah Dasar. Refleksi Edukatika : Jurnal Ilmiah Kependidikan, 7 (1): 27-31.

Sitio, Tiarmina. 2017. Penerapan Metode Jarimatika Untuk Meningkatkan Hasil Belajar Matematika Peserta Didik Kelas I SDN 003 Pagaran Tapah Darussalam Kabupaten Rokan Hulu. Jurnal Primary, 6 (1): 146-156.

Sugiyono. 2015. MetodePenelitian Pendidikan Pendekatan Kualitatif, Kuantitatif, dan $R \& D$. Bandung: Alfabeta.

Sumarni. 2016. Upaya Meningkatkan Kemampuan Berhitung Melalui Penerapan Model Pembelajaran Numbered Heads Together dengan Pemanfaatan Alat Peraga Sederhana Materi Pembagian Siswa Kelas 2. Refleksi Edukatika : Jurnal Ilmiah Kependidikan, 7 (1): 61-68. 
Ihsanudin dan Trian Pamungkas Alamsyah

THE USAGE OF JARIMATIKA METHODS TO IMPROVE COUNTING SKILLS ABILITY FOR ...

REFLEKSI EDUKATIKA : Jurnal Ilmiah Kependidikan 10 (1) Desember 2019. Hlm. 10-17

Taufik, M. 2014. Psikologi Pendidikan dan Bimpesdik. Serang: PGSD Press.

Turmudi. 2009. Landasan Filsafat dan Teori Pembelajaran Matematika (Berparadigma Eksplorasi dan Investigatif). Jakarta: Leuser Cipta Pustaka.
Wulandari, Christine. 2013. Pembelajaran Berhitung Penjumlahan dengan Jarimatika. BIOMA: Jurnal Keilmuan dan Kependidikan MIPA, 8 (1): 1-11.

Wulandari. 2012. Jarimatika: Perkalian dan Pembagian. Jakarta: PT Kawan Pustaka. 